\title{
The Application of Experiential Teaching in University Innovation and Entrepreneurship Education
}

\author{
Yanxia Tang \\ College of international Education \\ Jishou University \\ Jishou.416000.China \\ 344342371@qq.com
}

\begin{abstract}
Innovation and entrepreneurship education in universities has become the focus of the party and the state, and experiential teaching has been widely applied to innovation and entrepreneurship education in universities, which is beneficial for students to strengthen innovative entrepreneurial consciousness and improve innovative entrepreneurial ability in concrete situations. Therefore, this article from different perspectives of objective expounds the experiential teaching in use of the innovation of entrepreneurship education in universities, and proposes to establish "people-oriented" teaching philosophy. Meanwhile, science to enact an experiential teaching goal, and science setting up experience class to deeply integrate innovation and entrepreneurship education content, scientific applic ation of modern teaching methods to cultivate innovative entrepreneurial thinking. To carry out different forms of practice activities and improve the innovation and entrepreneurship ability, etc. Thus promote the comprehensive development of students to carry out the concept of talent cultivation in the new period.
\end{abstract}

Keywords-Experiential teaching, universities, Innovation and entrepreneurship education, application

\section{INTRODUCTION}

The experiential teaching is in line with the requirements of education for innovation and entrepreneurship in universities, the application and promotion value of experiential teaching is higher, which is an effective means to cultivate students' innovation and entrepreneurship quality in universities. College teachers should grasp the connotation and characteristics of experiential teaching at multiple levels. At the same time, they should also skillfully use the experiential teaching in innovation and entrepreneurship education, and in the depth of the fusion theory and practice of constantly promotes the development of students' thinking ability, make students have higher creative quality. Meanwhile, it can train a large number of innovative talents to fill jobs in the social sector. In addition, students are encouraged to continuously promote social and economic sustainable development in the realization of selfand social value, and effectively enhance the national comprehensive strength.

Fund Project: Research project of the 2017 degree and graduate education reform of Jishou University (JG2017B06)
II. The Application Value of Experiential Teaching in INNOVATION AND ENTREPRENEURSHIP EDUCATION IN UNIVERSITIES

Experiential teaching pays attention to students' subjectivity and subjective initiative, and individual differences. At the same time, it emphasizes the organic integration between perceptual knowledge and rational thinking, theoretical guidance and practice. In addition, it also emphasizes students' self-reflection and summary in the course of learning, which can connect the two major links of teaching and learning scientifically. The application of experiential teaching has a high value in the innovation and entrepreneurship education. Under the new situation, university innovation entrepreneurship education based on students' comprehensive quality training, and the application of experiential teaching is conducive to the students' allround and correct understanding of their own advantages and disadvantages in the diversified experience, combined with the connotation and requirements of education innovation and entrepreneurship in the new period, and constantly improve themselves. [1]Students in the process of learning curriculum theory knowledge, actively participate in various practice can help them to develop various aspects ability and quality, enhance their employment core competitiveness, and better realize their own value in innovative undertaking. On this basis, the application of experiential teaching in innovation and entrepreneurship education is conducive to strengthening the communication between schools and enterprises, so as to strengthen the connection between universities and local governments. With the support of local government departments, universities can better cooperate with various types of enterprises and strengthen the construction of industry-university-research bases. In the transformation and docking of industry-university-research, a good environment for innovation and entrepreneurship should be created to encourage the innovation and entrepreneurship of professional students. In addition, it can cultivate students' innovation and entrepreneurship ability and quality, and to help them become innovative talents. Synchronization can 
also promote the development of education in China's new era and social and economic development.

\section{The ApPlication of Experiential Teaching IN INNOVATION AND ENTREPRENEURSHIP EDUCATION IN UNIVERSITIES}

\section{A. Set up the "people-oriented" teaching concept, and develop the experiential teaching goal scientifically}

In the process of innovation and entrepreneurship education, universities should use the development vision to accurately grasp the training requirements of professional talents in the new period. In addition, the university should fully and deeply understand the experience teaching and innovation and entrepreneurship education, define the relationship between them, and establish the "peopleoriented" teaching concept. At the same time, the concept of "people-oriented" teaching through the creative education the experience type teaching in the process of using each link and give full play to the experience type teaching diversity, to promote the innovation of entrepreneurship education, setting the stage for cultivating innovative talents. In this process, teachers should start from the perspective of experience-oriented teaching, and adjust and innovate the education target scientifically based on the social market. [2]After that, teachers should formulate experiential teaching objectives according to the abilities of professional students, and integrate them into the innovation and entrepreneurship education target of innovation and entrepreneurship on a reasonable basis. To encourage teachers to develop the experience type teaching goal more targeted and effective, and encourage students innovative entrepreneurship education direction, encourage innovation entrepreneurship theory and practice of teaching smoothly, to carry out the "people-oriented" concept, to promote the all-round development of students' different levels.

\section{B. Scientific setting of experience courses, deep integrate innovation and entrepreneurship education content}

In the course of teaching management, universities should have a deep understanding of the current situation of innovation and entrepreneurship education. At the same time, universities should combine their own professional training objectives to set up experiential courses based on innovation and entrepreneurship, such as market research and innovation and entrepreneurship consultation. In addition, each university should also increase the proportion of curriculum practice teaching to promote the coordination and unification of curriculum theory and practice teaching. According to the courses and class schedules offered by each major, the university should arrange the teaching of experience-oriented courses in a phased and hierarchical way, which is based on the innovation and entrepreneurship of education. In this way, it can be integrated with specialized courses. [3]In addition, universities have to experience type teaching innovation and entrepreneurship education cleverly into the construction of campus culture, deepen the innovation of entrepreneurship education experience situation atmosphere, guide students to participate in the construction of campus culture of science. By using the knowledge of experiential courses based on innovation and entrepreneurship education to carry out innovation and entrepreneurship practice, the innovation and entrepreneurship education is put in the position of strategic goal realization. In this process, teachers should integrate innovation and entrepreneurship education content with the help of experiential content, and promote the effective integration of the two to create a good experiential teaching situation. In addition, teachers should also guide students to discuss, analyze and solve corresponding problems in the course of the course theory. Under the action of experience teaching, mastering some necessary creative knowledge can correct understanding on innovation entrepreneurship education, and be able to proceed to different aspects of the practice and scientific grasp of the theory of knowledge, effective to cultivate students' innovation ability.

\section{Scientific application of modern teaching methods to foster innovative entrepreneurial thinking}

The improvement of education level of innovation and entrepreneurship in universities is inseparable from good teaching methods. First, in the process of creative education, teachers should take the student as the guidance, scientific application of modern teaching methods, let the experience type teaching and the group cooperation study, role playing method and situational teaching method and so on the organic fusion. So as to build efficient innovation entrepreneurship education classroom. This will help students to deepen the theoretical knowledge of innovation and entrepreneurship in the diversified teaching situation, and cultivate students' abilities in all aspects in real time. And in the theory and practice of the two roles, training students innovative entrepreneurial thinking. In the process, teachers should adhere to the principle of teaching students according to their aptitude to respect individual differences. In addition, teachers should take experience-type teaching as a starting point and make scientific arrangements for innovation and entrepreneurship education content. Its difficulty should be moderate and meet the existing level of students in the class. What's more, the creative education theory explanation, the teachers should use opportunely role-playing method and case teaching method, etc..., effectively rendering experience type teaching atmosphere, in order to give full play to the functions of experiential teaching.[4] Teachers can combine the characteristics and functions of modern teaching methods, and set up a case analysis and role play to integrate the experience teaching situation. Meanwhile, teachers can also contact the hot spot of current innovation of entrepreneurship education, introduce the representative case of innovative undertaking into the classroom, including the innovation of the typical material business situation and some successful cases, such as in the interpretation of the creative education theory knowledge and the process of the students at all levels to discuss and analysis is introduced into the classroom. With the knowledge of innovation and entrepreneurship and the solution of innovation and entrepreneurship in specific cases, students can accurately understand the theoretical knowledge of innovation and entrepreneurship in solving case problems. Later, teachers can use group cooperative learning and role playing to ask students 
to focus on innovation and entrepreneurship education theme, and several people will arrange related performance programs. And the role is performed in the experiential teaching situation, effectively acquiring knowledge and emotional experience. As an example of "innovation risk", groups of students can play roles such as investors and entrepreneurs. In the experiential situation, we should grasp the complex entrepreneurial environment, correctly understand all kinds of risks in the process of innovation and entrepreneurship, and grasp the techniques of innovation and entrepreneurship risk aversion. And in the process of entrepreneurial innovation effectively hedge the risks from all sides, make the class in the concrete practice of the students at all levels of migration and the internalization of mastering theory knowledge, innovative undertaking and effective innovation entrepreneurship practice experience, training their creative thinking. So as to make students better to participate in the creative practice, dig their potential, real-time accurate improve their employment competitiveness, in the hope can smoothly on jobs after graduation.[5]

\section{Carry out various forms of practice, improve the innovation ability}

In the process of using experiential teaching, universities should use modern information technology and campus websites. In addition, online and offline combination methods can be used to create an experience teaching atmosphere, so that students can learn and apply innovative entrepreneurship theory knowledge to consolidate their theoretical knowledge of innovation and entrepreneurship. The university should focus on innovation and entrepreneurship education theory knowledge, and carry out different forms of innovation and entrepreneurship education practice activities, effectively connecting with innovation and entrepreneurship theory and practice teaching. [6]At the same time, in the multilevel innovation and entrepreneurship education practice, science guides students skillfully use innovation and entrepreneurship as well as the theoretical knowledge of professional courses, while improving students' innovation and entrepreneurship and professional ability. In this process, universities should pay attention to the improvement of the practical training and internship equipment in the university, and carry out the practice activities of various forms in the medium term with professional courses teaching. In this way, we can create a special experiential teaching situation for students, and acquire the knowledge of entrepreneurship and emotional experience in practice. Universities should adopt the way of cooperation with enterprises, and take innovation and entrepreneurship education as the starting point to construct the practical training and practice base on campus, so as to provide a good platform for innovation and entrepreneurship of students. In addition, universities can conduct in-depth cooperation with enterprises around the goal of experiential teaching concept and professional personnel training. Universities can also use opportunely various aspects advantage resources to creating business industry base of science, at the same time, they should also be clear creative projects and funds, and in different forms of creative practice. Meanwhile, universities should also arrange professional teachers encourage students to real-time bold innovation and entrepreneurship, science to guide the student should be able to do an objective analysis and dig entrepreneurial projects of intrinsic value, science to develop innovative business planning and scheme, creative thought. In the process of avoiding the risk of innovation and entrepreneurship, let students effectively carry out innovative entrepreneurial practice, and let them continue to experience various aspects in specific positions to further their career planning and cultivate their own innovative and entrepreneurial ability. [7] On the basis of understanding of the dynamic variation of the social market students have more chances of employment, which can make students better in a competitive market shows all aspects of their own value. In addition, universities should skillfully use the modern evaluation mechanism and methods, comprehensively and objectively assess the innovation and entrepreneurship practice of students at all levels. Problem oriented and based on experiential teaching media, undertake to the student targeted innovation entrepreneurship practice, in the deep practice effectively stimulate students' entrepreneurial zeal, and real-time cultivate their creative consciousness and spirit, so that they possess the high innovation practice ability. [8]At the same time, universities should be under the effect of innovation entrepreneurship education improve the comprehensive quality of students in different levels in the same professional, implement innovative talents training target, to better show innovation entrepreneurship education experience type teaching glamour.

\section{CONCLUSION}

In a word, colleges and universities should grasp the problem of innovation and entrepreneurship education, and use students as the center to apply experiential teaching. In this way, universities can play a better role in the innovation and entrepreneurship of education. This has prompted students in knowledge and the emotion experience constantly thinking, exploration and innovation, effectively stimulate their feelings as well as the potential, and constantly update their knowledge, deepen the knowledge structure system. In the end, students can effectively improve their knowledge application, practice and employment ability, and become the high-level talents needed in the new period. In this way, we can achieve the goal of cultivating talents in colleges and universities, and have higher education level, and promote the continuous development of education in China's new era.

\section{REFERENCES}

[1] Deng lian. The application of experiential teaching in innovation and entrepreneurship education [J]. Education observation (last month), 2016, 5(6):25-26.

[2] Hu haishan, du wenbo, Chen ping and others. The path analysis of innovation and entrepreneurship education into the whole process of talent cultivation in universities [J]. Experimental technology and management, 2013, 34(9):27-29.

[3] Ding jun miao. Innovation and entrepreneurship education led the reform and development of education -- three stages of innovation and entrepreneurship education and the new historical mission of universities [J]. Innovation and entrepreneurship education, 2016, 7(1):1-6.

[4] Duan Haichao, Pu Qingping, Wang Zhen and others. On the value orientation of education in innovation and entrepreneurship in 
universities -- a reflection on the individual level of socialist core values [J]. School party construction and thinking, 2016, (17):74-77.

[5] Wang geng. The current dilemma and path selection of innovation and entrepreneurship education in universities [J]. Journal of south China normal university (social science edition), 2015, (6):140-144.

[6] Zhang qi. Innovation and entrepreneurship education new model: innovation and entrepreneurship education combined with quality development experiential teaching [J]. Industry and technology BBS, 2012, (14):125-126.
[7] Li Yueheng, Zhang Yanzhong. Implementation path of innovative Entrepreneurship Education in universities based on refined Management Theory [J]. Education and occupation, 2017, (3):64-68.

[8] Gao guijuan, zhou shangjiu, hu jing and others. Exploring the entrepreneurial ability of college students through experiential teaching [J]. University: academic edition, 2012, (10):42-48. 